\title{
Ripping Open the Wound to Get Back at the Knife
}

\author{
Jack Myers
}

Whenever heroic figures emerge, you'll find what they've won they've left behind. They are necessarily insatiable. So Jon Anderson's discoveries harden into artifacts, fossilized remnants of the changes he's gone through, not to make discoveries, but to keep going. That's what he gives me, this forced march toward himself. And when he talks straight, I find myself enlisting with my own baggage of deaths, loneliness, marriage and sex. You say so what . . . the Sun's Anvil is a place staked out in all of us. That's not news. But the impetus between each temporary triumph and failure is. What you call dramatic comes natural. No one cheers because ten million brain cells replace themselves every minute. But if this process were slowed down so you could see this amazing ability in slow motion, would you stay for the second show? Would you ever leave?

Let's not pretend the pronouns in Jon's poems are antiseptic representations of you, me and him. Either they are really us, or they aren't important. I think he's dealing with us as equals, sometimes as victims. When he doesn't want us following him, he'll lay down a lush music we fall into and leave behind "graceful verses . . . boats loaded with spiced meats \& jewels . . . a silence meant to kill." He'll feed us indulgences which ultimately weaken and poison our will to stay on top of the punishment this seduction leads to. No matter how you view your condition after one of his poems, the technique has obvious shock value. And the words written on the outside surface of the poem also describe the inner workings. The "silence meant to kill" is the absence of process, words solidified into the structure of the trek which Jon uses as steps toward his grim resolutions. By sliding sound associations and a zig-zag logic, he leaves the reader face down on his discoveries. That's an indication of how well, how deeply he reads other poets' work. His art and cunning are in the way he backtracks, picks up the battered reader and reinstates him as companion: "So you talk about death," then he jams it down your throat and tries to reveal you: "Is it sweet, that you love it so?" It's a kind of Russian roulette with no winners. His drive is implacable. Almost against his will he calls you a poor bastard and slant rhymes into admitting you may be still capable of giving affection, though it's offered like alms. This kind of ambivalence will change or reinforce your vision of yourself. Over and over, like a Zen initiate, Anderson slaps his own face for giving the wrong answer. The answer is the slap. The point is "not to win" and at the same time "not give in" because "these refusals begin to look like courage." This unique strategy of his poems comes from the way he almost beats himself to death, leaving just enough consciousness to keep "thumping \& shooting . . . under mysterious orders not to come in." He has come to be a first-rate poet by taking himself on, and making the poem take on the reader as well. As in the Eastern martial arts, momentum is the weapon. Every move circles back into a move against itself. The object is to reach some kind of ultimate refusal which escapes 
deathlock after deathlock by refusing itself. As Olson said, "What does not change/ is the will to change."

Mixing kindness with the same sort of brutal courage in "Though I Long to Be No One," Jon achieves another variation on psychological self-destruction. He has friends and women, lots of them. But hell keep their company only as phantoms in his sleep because "Whoever's face I lay my own along/ the cheek bones bruised \& rose." This capacity to portray himself, set up his forces of conflict, and involve the reader's empathy, is where he gets his tension, and later on, release. It's all so very unassuming it lulls us into a false security. Another special trick is in the way he sets up rather ordinary diction and then transforms it into the quality abstractions which have become the hallmark of his style. He does it by making parallels which extend beyond themselves. It follows the same logic that creates conflict in order to arrive at a new order of understanding. We learn that his friends' faces are really "the bodies of his constant departure." And his wanting to be no one, is wanting to be No One, a transubstantiation into one with his constant longing. The verbal play between "I long to be no one" and "no one into constant longing" is the kind of unconscious art that fills his poems with the power to fuse contradictions. It's his sheer will that turns his deceptions inside out.

While Jon, like a lot of modern poets, looks at an undefined basic flaw in his life, he does it with the resignation of an amputee speaking to the hand that won't grow back: "I suppose this error will continue." Though the sounds are feminine, the voice has the cold acceptance of an experienced (I almost said hand) man. There's none of the pitiful confessional squealing that becomes maudlin after a few lines. He sees his task as setting the immovable object uptight against the irresistible force: thinking of death makes him lonely, but the loneliness of death is unendurable. Like Houdini, he has locked himself into the satisfaction of the crowd and gets himself out by going deeper into the problem to discover its weakness. Of course the weakest component is the crowd. They will let a cut flower sip its aspirin in a vase and admire the flower's common beauty. Jon makes them see the cold loneliness of death's beauty which would "leave you inconsolable all day." He lets us assume there's a way out, a key to unlock the situation, but he offers us the reverse. The way to conquer pain is to become one with it, to will yourself beyond pain by consuming it. So courage still comes at the same high price. Jon has made this strategy his art. It's a natural extension of his earlier work, like "The Parachutist," where that deadly act of rest, falling, drops him through the space outside his friends' worlds into the cliché judgments of society. And that's an accurate description of where Jon's weakness lies, in his deference to the expectations of those around him. As a result he replaces us with himself and there's murder in his eye. Though you might leave it up to him, you have to admire the way he punches his way toward love. You must believe him when he says "The secret of poetry is cruelty." 


\section{Jon Anderson's Respønse}

Jack's comments are eloquent \& disturbing, incredibly accurate in defining most of the motivation of my poems. But where he finds (thanks, Jack) a kind of courage in their continual confrontation, I suspect a limiting obsession, a refusal to allow human solace or joy until all the psyche's confusions have been resolved. This is not to disown confrontation-I hope, with Jack, that we're writing to frighten ourselves into honesty so that, in the end, we can understand \& thereby love ourselves, the world.

But I think I've been hoping for an overload of self-conflict that would not so much cohere as short-circuit. The rewards of aggressive confrontation are only a kind of painful, short-term resurrection: the worst has been faced, \& it terrifies \& excites. But there's more-the desire to pass through personal pain toward some mortal grief, or grief of mortality, that enlarges our lives. It's in Jarrell \& Robinson, Roethke \& Wright. Instead of awakening themselves through agrressions, they use vulnerability. At its worst it's self-pity, but at its best it extends into the humane. They have no interest in power.

Books like Wright's Two Citizens \& Robert Penn Warren's Audubon: A Vision refresh \& heal me, because the voice of the poet has taken its place in the human myth of mortality. "Tell me a story," says Penn Warren, \& the story is our lives' unwinding. The voice desires not to confront, but to describe; not to be honest, but true.

Once a year I get together with my best friends. We drink \& talk, share our fears \& trade advice. It's like writing a poem-the complex emotional forces of the past year become articulate, specific, more real \& changeable. Obsessions dissolve into self-description. In the company of love, we can wholly afford ourselves.

I'd like to write poems that invite such company. 